\title{
THE EFFECT OF SODIUM GLUTAMATE ON HEPATIC COMA ${ }^{1,2}$
}

\author{
By LESLIE T. WEBSTER, JR., AND CHARLES S. DAVIDSON \\ (From the Thorndike Memorial Laboratory, Second and Fourth Medical Services [Harvard], \\ Boston City Hospital, and the Department of Medicine, Harvard Medical School, \\ Boston, Mass.)
}

(Submitted for publication February 14, 1955; accepted October 17, 1955)

Abnormalities of nitrogen metabolism may be important in the production of hepatic coma (1). This concept is supported by the following: 1 ) Elevated blood "ammonia" ${ }^{8}$ concentrations have been described in patients with cirrhosis of the liver, many of whom were in hepatic coma; the highest values have occurred in comatose patients. 2) Some alcoholic patients with cirrhosis given nitrogenous substances including ammonium cation-exchange resins, ammonium salts, urea, and increments of dietary protein have developed impending hepatic coma (mental confusion and often the characteristic "flapping" tremor) which usually terminated after discontinuing these substances $(2,3)$. 3) A similar state occurred also in Eck fistula dogs and man after feeding increments of dietary protein and other nitrogenous substances (4-6).

Ammonium may react with glutamic acid to form glutamine or precursors of urea. Glutamic acid is used more than any other amino acid in brain energy metabolism, and has been reported to improve insulin coma in psychotic patients (7, 8). Walshe first used glutamic acid in the treatment of hepatic coma with encouraging results (9). Other investigators have since reported variable findings $(10-20)$. This paper evaluates the effect of intravenous sodium glutamate administered to eleven patients with cirrhosis of the liver. Five were comatose, six showed signs of

1 This work was supported in part by the Office of The Surgeon General, Department of the Army, and in part by a grant from Merck and Company, Inc., Rahway, New Jersey, to Harvard University.

${ }^{2}$ A preliminary report of part of this investigation is included in the Proceedings of the Forty-Sixth Annual Meeting of the American Society of Clinical Investigation, Atlantic City, May 4, 1954 (J. Clin. Invest., 1954, 33, 971).

8 Whether free ammonium exists in shed blood or forms after shedding is argued. If it does exist it is present as ammonium ion. Therefore, when referring to plasma or blood, we have put the word ammonia in quotes. spontaneous ${ }^{4}$ impending coma, and two had signs of impending coma which had been induced by ammonium salts.

\section{MATERIALS AND METHODS}

Patients. Five patients were men and six women, ranging in age from 34 to 67 years. In all but one, the diagnosis of cirrhosis was made by history of heavy alcohol and poor food intake coupled with physical and laboratory findings consistent with severe longstanding liver disease. The exception was a woman (A. R.) with presumed biliary cirrhosis. Nine patients died in hepatic coma and the diagnosis of cirrhosis was confirmed in seven at autopsy and in one by needle biopsy. In addition to cirrhosis one patient (J. H.) was found to have a co-existing chronic cholecystitis with cholelithiasis, another (J. W.) a small old encapsulated subdural hematoma, and a third (J. K.) bronchiogenic carcinoma with liver metastases as well as a primary carcinoma of the rectosigmoid and prostate. Four patients had hemolytic anemia thought to be consistent with their liver disease. (See Table I.) Guaiac positive stools were obtained in patient $J$. K. throughout treatment and patient A. P. vomited and aspirated guaiac positive material terminally, there was no evidence of gastrointestinal bleeding in the other patients.

Glutamate and ammonium salts. L-glutamic acids was given as sodium glutamate already prepared by the manufacturer or prepared as follows: 20 grams of 1-glutamic acid were neutralized with 20 per cent sodium hydroxide to a $\mathrm{pH}$ of 7.4 to 7.8 and made up to a volume of from 300 to $1000 \mathrm{ml}$. with sterile 5 per cent glucose in distilled water. This mixture, containing approximately 23 grams of sodium glutamate, was given intravenously during a 3 to 4-hour period in the afternoon to eight patients; three received from 103 to 355 grams continuously over a period of from 17 to 93 hours. The only reactions were anorexia and vomiting controlled by slowing the rate of infusion. Di-ammonium citrate was given in 4-gram doses five times during the day (daily dosage of 20 grams). Ammonium chloride was given in half-gram enteric-coated tablets, 2 grams every two hours during the daytime, to total 10 grams daily.

\footnotetext{
4 "Spontaneous" is the term used to describe coma or impending coma in which precipitating factors, except severe liver disease, were not known.

${ }^{5}$ Kindly provided by Dr. Augustus Gibson, Merck \& Co., Rahway, New Jersey.
} 
Diet. Patients were maintained on 2000 to 2400 calorie diets with not more than 66 grams of protein. Only patient J. H., who had undergone a previous period of protein depletion without marked beneficial response, received less protein during treatment than before. Because nine patients had ascites and ten had edema, daily dietary sodium intake was restricted to approximately 200 milligrams. Patients unable to eat received a similar diet by tube or 10 to 15 per cent glucose by vein. Twentyfour-hour fluid intake was adjusted to equal the estimated fluid lost with occasional exceptions when a water load was given.

Laboratory methods. The total 24-hour urine volumes were recorded. Blood was drawn about 1 to 2 hours after breakfast. Serum determinations were carried out as follows: Carbon dioxide content as described by Van Slyke and Neill (21); sodium and potassium concentrations by internal standard flame photometry (22); chloride concentration by the iodometric titration of Van Slyke and Hiller (23); and urea nitrogen concentration according to Owings and Mandel (24). Liver function studies including 45-minute serum bromsulphalein retention, cephalin flocculation, thymol turbidity and flocculation, and serum bilirubin concentrations were performed at weekly intervals using standard methods. Icterus index, hematocrit, and urine urobilinogen were measured at more frequent intervals.

The blood "ammonia" content, expressed as ammonia

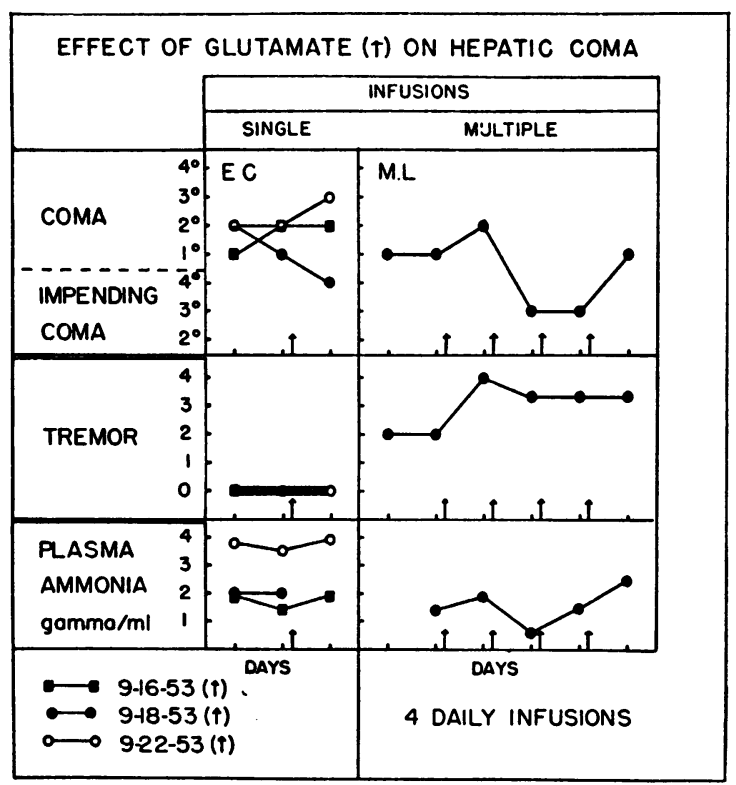

Figure 1

Two patients were given $23 \mathrm{gm}$. of sodium glutamate as indicated by the vertical arrows, E. C. one infusion on three separate occasions on the dates shown (left of figure), and M. L. four consecutive daily infusions (right of figure). Plasma "ammonia" is expressed as $\mathrm{NH}_{2}$ nitrogen.

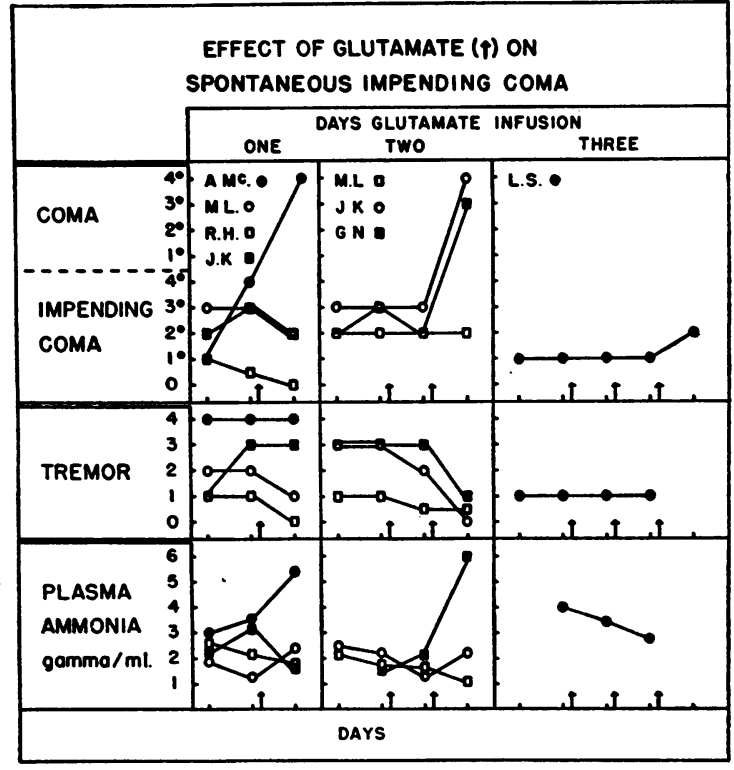

Figure 2

Twenty-three $\mathrm{gm}$. of sodium glutamate, as indicated by the vertical arrows, were given to 4 patients on a single occasion (left of figure), to 3 patients on two consecutive days (center of figure), and to 1 patient on three consecutive days (right of figure). Plasma "ammonia" is expressed as $\mathrm{NH}_{3}$-nitrogen.

nitrogen $\left(\mathrm{NH}_{8}-\mathrm{N}\right)$, was determined by a modification of the Seligson method (25) in the first eight patients and by McDermott and Adams' (6) modification of the Conway technique in the last three. Further modifications of the Seligson technique were: 1) The determination was always done on freshly collected plasma and 2) rotation was carried out for a period of one hour at $28^{\circ} \mathrm{C}$. instead of $23^{\circ}$ as described. Values for volatile plasma base by this method were lower than those obtained by Kirk (26) but in the same range as those obtained by Seegmiller, Schwartz, and Davidson (25). Daily variations were marked but duplicate samples checked well. The second technique utilized whole blood instead of plasma, and a ten-minute time limit was employed for diffusion of volatile blood base into the acid center well. Here, values ranged from 0.25 to 0.7 gamma of $\mathrm{NH}_{8}-\mathrm{N}$ per milliliter of normal blood and from 0.35 to 1.0 gamma per milliliter of blood in patients with cirrhosis without mental symptoms. Of the two ammonia methods used, the second (McDermott and Adams' modification (6) of the Conway technique) has yielded lower values and has proved much more reproducible and reliable in our hands although its results do not consistently reflect changes in consciousness. $\mathrm{NH}_{3}-\mathrm{N}$ determinations were done daily in the mornings on the first eight patients who received no more than 23 grams of sodium glutamate per day; determinations were done much more frequently in the last three cases who received larger amounts.

Clinical evaluation. The state of consciousness, the 
most reliable method for evaluating hepatic coma, was classified daily into sub-groupings of coma or impending coma to document accurately change and to allow comparison from patient to patient. Many well-known signs, i.e., fetor hepaticus, abnormal plantar and deep tendon reflexes, ankle clonus, flaccidity, convulsions, etc. were not included because none of these occurred consistently at a given depth of coma. This classification is not complete; also some cases of hepatic coma will not fit precisely into the pattern described (27).

Two main divisions were set-up-impending hepatic coma (including both spontaneous impending coma and impending coma induced by ammonium salts), and hepatic coma. The former was characterized by confusion and disorientation and the latter by loss of consciousness.

Impending coma was divided into five subheadings as follows:

1. Questionable impending coma. The patient often "did not feel quite right," exhibited a change in emotional tone, or did not possess his usual mental agility. Obvious confusion was present only at night.

2. First degree impending coma. Reasoning, such as ability to perform calculations, was impaired but orientation as to time was present. Often a change in personal tidiness and a "far away look" (28) in the eyes were observed.

3. Second degree impending coma. Response was delayed and confusion was easily brought out by simple conversation. Orientation was present to place but not to time.

4. Third degree impending coma. Response to questioning was grossly inaccurate, delayed, and slow; simple phrases were used. Somnolence was apparent; orientation to place and time was absent.

5. Fourth degree impending coma. Drowsiness and confusion were marked; spoken response was delayed, slow, irrelevant, monosyllabic, and often incoherent.

Coma was divided into four subheadings: Spoken response was absent, unlike impending coma.

1. First degree coma. Responses to spoken voice, such as motion, grimacing, groaning, or turning the eyes, were observed.

2. Second degree coma. Response was absent to voice but present to painful stimuli which produced motion, change in respiration, and perhaps grimacing. Corneal and gag reflexes were present.

3. Third degree coma. Painful stimuli produced, if any response, only a change in respiration. Either or both corneal and gag reflexes were present.

4. Fourth degree coma. Painful stimuli produced no response; gag and corneal reflexes were absent.

A common sign particularly in impending hepatic coma is the "flapping tremor" described by Adams and Foley in 1949 (29). This is a coarse asynchronous flexion-extension movement occurring in one or more muscle groups depending on its severity. It is best demon-

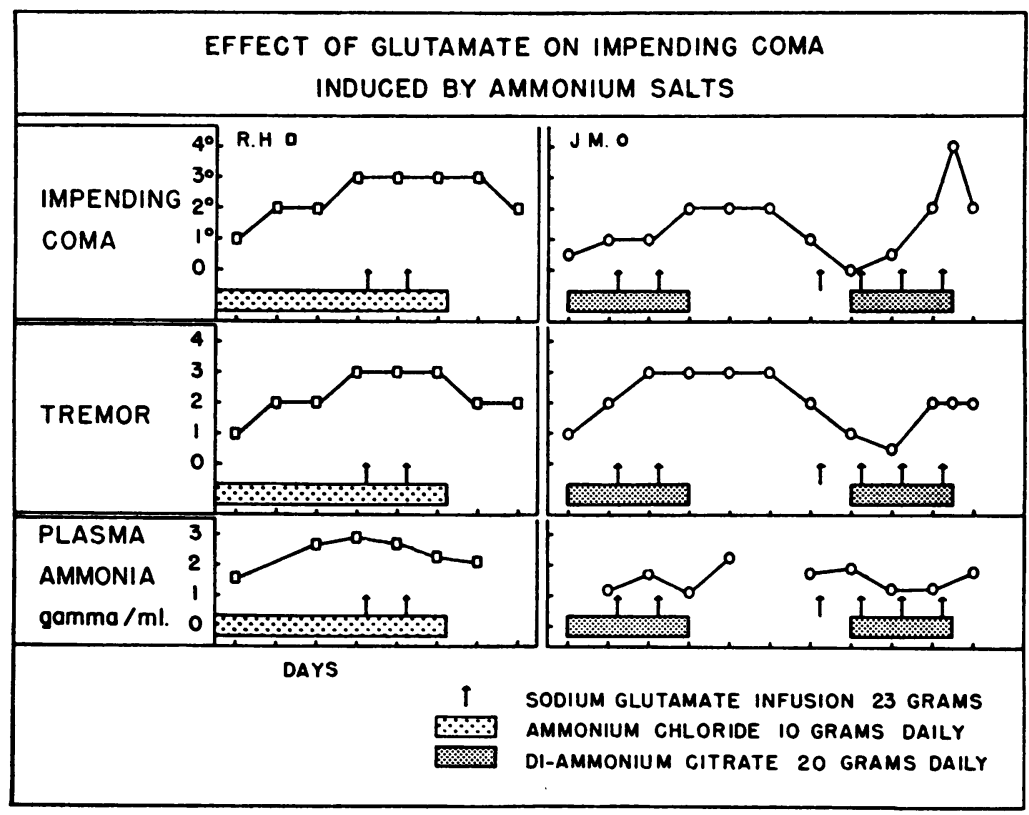

Figure 3

Twenty-three gm. of sodium glutamate, indicated by the vertical arrows, were given on two consecutive days to patient $R$. $H$. along with ammonium chloride (left of figure), and to patient J. M. both before and during diammonium citrate administration (right of figure). Plasma "ammonia" is expressed as $\mathrm{NH}_{3}$-nitrogen. 
strated by spreading the fingers and hyperextending the hand at the wrist with the pronated arm resting on the bed. In comatose patients the tremor often is elicited only when the hand is passively flexed at the wrist or held by the observer; it is not elicited when the limb is flaccid. The tremor was graded from $1+$ to $4+$ as follows :

$1+$ Definite tremor was present only with outstretched arms resting on the bed and hands hyperextended as described.

TABLE I

Clinical and laboratory data on the 11 patients with cirrhosis of the liver

\begin{tabular}{|c|c|c|c|}
\hline $\begin{array}{l}\text { Patient } \\
\text { Age } \\
\text { Sex }\end{array}$ & History and physical signs & $\begin{array}{c}\text { Laboratory } \\
\text { (range of values) } \\
\text { Hematocrit \% } \\
\text { Serum bilirubin } \\
\text { (mg./100 ml.) } \\
\text { Bromsulphalein } \\
(\% \text { retention) })\end{array}$ & Disposition and comments \\
\hline \multicolumn{4}{|c|}{8 patients receiving a maximum of 23 grams of sodium glutamate per day } \\
\hline $\begin{array}{l}\text { M. L. } \\
64 \\
\text { M }\end{array}$ & $\begin{array}{l}\text { *Icterus, angiomata, pallor, hepa- } \\
\text { tomegaly, ascites, edema. }\end{array}$ & $\begin{array}{l}24-29 \\
5.3-10.0 \\
35-57\end{array}$ & $\begin{array}{l}\text { Hemolytic anemia. Died after } 33 \text { days of coma. } \dagger \\
\text { Postmortem: Laennec's cirrhosis, arteriosclerotic } \\
\text { heart disease. }\end{array}$ \\
\hline E. C. & $\begin{array}{l}\text { Paracentesis 9-8-53. Marked } \\
\text { ascites and edema. }\end{array}$ & $\begin{array}{c}29-35 \\
1.7 \\
53\end{array}$ & $\begin{array}{l}\text { Died 9-24-53 after } 14 \text { days of coma. } \dagger \text { Postmor- } \\
\text { tem: Laennec's cirrhosis. }\end{array}$ \\
\hline $\begin{array}{l}\mathrm{J} . \mathrm{K} \\
\mathbf{6 7} \\
\mathrm{M}\end{array}$ & $\begin{array}{l}\text { History of } \mathrm{NH}_{4} \mathrm{Cl} \text { ingestion and } \\
\text { diarrhea. Icterus, angiomata, } \\
\text { hepatomegaly, ascites, edema. }\end{array}$ & $\begin{array}{l}47-51 \\
5.7-9.0 \\
46\end{array}$ & $\begin{array}{l}\text { Stools benzidine positive. Abnormal chest and } \\
\text { barium enema films. Died after } 16 \text { days coma. } \dagger \\
\text { Postmortem: Laennec's cirrhosis. Primary car- } \\
\text { cinoma of the bronchus, rectosigmoid, and pros- } \\
\text { tate. }\end{array}$ \\
\hline $\begin{array}{l}\text { G. N. } \\
49 \\
M\end{array}$ & $\begin{array}{l}\text { *Icterus, angiomata, hepatomeg- } \\
\text { aly, ascites, edema. }\end{array}$ & $\begin{array}{c}46-50 \\
19.2\end{array}$ & $\begin{array}{l}\text { Died after } 7 \text { days of coma. } \dagger \text { No postmortem or } \\
\text { liver biopsy obtained. }\end{array}$ \\
\hline $\begin{array}{l}\text { A. Mc. } \\
\text { F4 } \\
\text { F }\end{array}$ & $\begin{array}{l}\text { History G.I. bleeding stopping } \\
7 \text { days prior to coma. } \dagger \text { Ic- } \\
\text { terus, angiomata, ascites, } \\
\text { edema. }\end{array}$ & $\begin{array}{c}29-32 \\
22.8 \\
57 \\
-\end{array}$ & $\begin{array}{l}\text { Died after } 4 \text { days of coma. } \dagger \text { Postmortem: Laen- } \\
\text { nec's cirrhosis, hypertensive cardiovascular dis- } \\
\text { ease. }\end{array}$ \\
\hline $\begin{array}{c}\text { L. S. } \\
37 \\
\text { F }\end{array}$ & $\begin{array}{l}\text { "Icterus, pallor, hepatomegaly, } \\
\text { edema. }\end{array}$ & $\begin{array}{r}25-26 \\
24.4-46 \\
67\end{array}$ & $\begin{array}{l}\text { Hemolytic anemia. Died suddenly after } 6 \text { days of } \\
\text { impending coma. Liver needle biopsy: Great } \\
\text { increase in fat, little fibrosis. No postmortem } \\
\text { obtained. }\end{array}$ \\
\hline $\begin{array}{c}\text { R. H. } \\
49 \\
\text { M }\end{array}$ & $\begin{array}{l}\text { History paracentesis and paral- } \\
\text { dehyde. Icterus, angiomata, } \\
\text { ascites, edema. }\end{array}$ & $\begin{array}{c}38-49 \\
1.3-2.0 \\
29-51\end{array}$ & $\begin{array}{l}\text { Spontaneous improvement after } 20 \text { days of im- } \\
\text { pending coma. Impending coma induced by } \\
\text { ammonium salts. No symptoms of coma since. } \\
\text { Liver biopsy not done. }\end{array}$ \\
\hline $\begin{array}{l}\mathrm{J} . \mathrm{M} \\
\mathbf{3 4} \\
\mathrm{M}\end{array}$ & $\begin{array}{l}\text { *Icterus, angiomata, ascites, } \\
\text { edema. }\end{array}$ & $\begin{array}{c}33-39 \\
6.1-8.2 \\
38-53\end{array}$ & $\begin{array}{l}\text { Impending coma induced by ammonium salts. } \\
\text { Died months later in hepatic coma. }\end{array}$ \\
\hline \multicolumn{4}{|c|}{3 patients receiving more than 23 grams of sodium glutamate per day } \\
\hline $\begin{array}{l}\text { J. H. } \\
49 \\
\text { F }\end{array}$ & $\begin{array}{l}\text { *Angiomata, pallor, ascites, } \\
\text { edema. }\end{array}$ & $\begin{array}{c}24-26 \\
2.9 \\
36\end{array}$ & $\begin{array}{l}\text { Died after } 4 \text { months comat and } 5 \text { days after sodium } \\
\text { glutamate. Postmortem: Laennec's cirrhosis, } \\
\text { chronic cholecystitis and cholelithiasis. }\end{array}$ \\
\hline $\begin{array}{l}\text { J. W. } \\
46 \\
\text { F }\end{array}$ & $\begin{array}{l}\text { *History head trauma } 6 \text { wks. pre- } \\
\text { viously and } 1 \text { day of confusion. } \\
\text { Icterus, angiomata, hepato- } \\
\text { megaly. }\end{array}$ & $\begin{array}{l}32-34 \\
24.5 \\
-\end{array}$ & $\begin{array}{l}\text { Died after } 5 \text { days coma }{ }^{\prime} \text { during glutamate admin- } \\
\text { istration. Postmortem: Laennec's cirrhosis, } \\
\text { small encapsulated subdural hematoma. }\end{array}$ \\
\hline $\begin{array}{l}\text { A. P. } \\
\text { F }\end{array}$ & $\begin{array}{l}\text { History of operation } 9 \text { days pre- } \\
\text { viously and leakage of ascitic } \\
\text { fluid. Icterus, angiomata, } \\
\text { hepatomegaly, ascites. }\end{array}$ & $\begin{array}{l}34-37 \\
24 \\
-\end{array}$ & $\begin{array}{l}\text { Died after } 7 \text { days coma } \dagger \text { during glutamate adminis- } \\
\text { tration. Postmortem: Biliary cirrhosis, blood } \\
\text { in upper gastrointestinal tract, aspiration of } \\
\text { stomach contents. }\end{array}$ \\
\hline
\end{tabular}

* Only factor known to precipitate coma was severe liver disease.

$\dagger$ Onset of coma dated from the onset of confusion.

¥ Per cent retention of B.S.P. measured in the serum 45 minutes after $5 \mathrm{mg}$. of dye per kilogram body weight was injected intravenously. 
$2+$ The tremor was present with arms held outstretched off the bed and hands dorsiflexed at wrists. A similar tremor was elicited when the feet were dorsiflexed.

$3+$ Tremor was prominent in the hands, feet, and also was present in other muscle groups.

$4+$ The tremor was sufficiently severe to interfere markedly with voluntary motor acts.

According to their states of consciousness, the first eight patients who received a maximum of 23 grams of sodium glutamate per day were placed in one of three groups on the day of the initial glutamate infusion as follows: 1) coma, 2) spontaneous impending coma, 3) induced impending coma (see Figures 1-3). Those who exhibited first to fourth degree coma made up Group 1. Those who exhibited impending coma without precipitating factors made up Group 2. The two patients who received ammonium salts with subsequent development of tremor and confusion comprised Group 3. All patients remained in their original group until observations following single or multiple infusions of sodium glutamate were completed. If a lag of one or more days took place between glutamate infusions, the patient was regrouped if warranted (see patient M. L.).

None of these eight patients received adrenal steroid hormones, supplementary potassium salts, or antibiotics. The three remaining patients who received large quantities of glutamate were all comatose and were classified into subheadings of coma as previously described. Two of these, E. C. and A. P., received supplementary oral potassium salts and one, A. P., received cortisone and antibiotics in addition to glutamate. With two exceptions, R. H. and E. C., infusions were administered when confusion or coma was either progressive or stabilized in all eleven patients.

\section{RESULTS}

Pertinent history, physical signs, hematocrit, serum bromsulphalein retention, serum bilirubin, and disposition of the eleven patients are given in Table I. Table II presents clinical and laboratory data before and after the glutamate infusions and Figures 1, 2, and 3 present by groups the changes in mental state, tremor, and plasma $\mathrm{NH}_{3}-\mathrm{N}$ concentrations of the eight patients who received a maximum of 23 grams of glutamate per day. The remaining three comatose patients who received larger quantities of glutamate are later presented in more detail.

Two of the first eight patients, one receiving glutamate on three separate occasions and the other on four consecutive days, were comatose. Neither patient demonstrated any consistent changes in mental status, tremor, or plasma $\mathrm{NH}_{3}-\mathrm{N}$ levels. In the impending coma group,

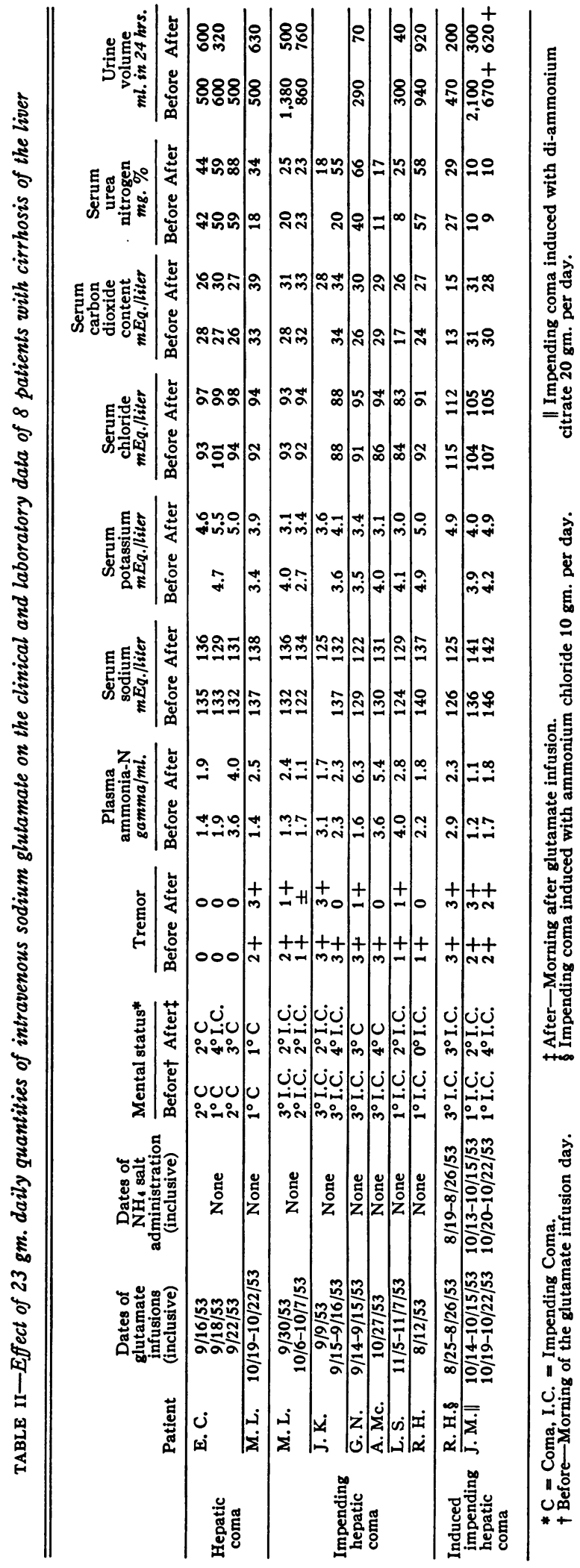


four patients received a single glutamate infusion, three patients an infusion each of two successive days, and one patient three infusions at daily intervals. After glutamate three of these patients became worse and died, three improved slightly, and one showed no change in mental status. Tremor remained the same or decreased in all of this group and plasma $\mathrm{NH}_{3}-\mathrm{N}$ concentrations rose in two, remaining essentially unchanged in the others.

Two patients in whom impending coma was induced by oral ammonium salts were given infusions of sodium glutamate in addition to their ammonium salts. Patient R. H. exhibited no change in confusion or tremor although the plasma $\mathrm{NH}_{3}-\mathrm{N}$ levels fell slightly after glutamate. $\mathrm{Pa}-$ tient J. M. became more confused and his tremor also became accentuated despite two consecutive daily infusions of glutamate. Later, glutamate, given prior to and during administration of di-ammonium citrate, failed to prevent the onset and exacerbation of impending coma or accentuation of tremor in the same patient.

The results of the other laboratory determinations performed on the first eight patients are given in Tables I and II. Serum sodium and potassium concentrations were often lower than normal but consistent changes did not occur after sodium glutamate. Likewise, no consistent variations occurred in serum chloride concentrations which were initially low in most patients and high only in the patient receiving ammonium chloride. Serum carbon dioxide contents rose more than $3 \mathrm{mM}$ per L. only in three patients who received sodium glutamate for at least two days. Serum urea concentrations rose more than $15 \mathrm{mg}$. per cent in five patients, two of whom had become markedly oliguric.

The first patient, J. H., received 103 grams of sodium glutamate in 17 hours, 75 grams of which were given during the first 10 hours. Her blood $\mathrm{NH}_{3}-\mathrm{N}$, initially markedly elevated (3.45 gamma per ml. of blood), dropped promptly to within normal limits where it remained on 12 occasions until $4 \frac{1}{2}$ hours after glutamate was discontinued, when it rose again to abnormal levels. Her mental status, initially second degree coma, improved to first degree coma after two hours, and to fourth degree impending coma just as the infusion was discontinued. She then improved further to third degree impending coma where she remained for 3 days until two days before death. The $2+$ tremor disappeared during and after glutamate therapy. Biochemical changes observed during her treatment were a drop in serum potassium concentration from 4.3 to $3.2 \mathrm{mEq}$. per 1 , a rise in serum carbon dioxide content from 25 to $38 \mathrm{mEq}$. per 1., and a rise in serum sodium concentration from 134 to $147 \mathrm{mEq}$. per 1. Twenty-four-hour urine sodium output remained the same as previously (approximately .5 to $1.5 \mathrm{mEq}$.), potassium rising from 20 to $60 \mathrm{mEq}$. per 24 hours on the day of sodium glutamate administration.

The second comatose patient, J. W., received 175 grams of sodium glutamate over a period of 35 hours, and improved from third degree to second degree coma in 12 hours. During this period she developed twitching of the arms and legs. Following this short period of improvement she developed oliguria, hypotension, slipped into fourth degree coma, and died. Blood $\mathrm{NH}_{3}-\mathrm{N}$ concentrations, determined on six occasions, were normal before and remained normal during glutamate therapy. The tremor was not present during her comatose state. Despite administration of 180 $\mathrm{mEq}$. of intravenous potassium, her serum potassium concentration dropped from 3.2 to $1.5 \mathrm{mEq}$. per 1. during sodium glutamate treatment. Serum sodium concentration rose from 125 to $132 \mathrm{mEq}$. per 1 . and carbon dioxide content was found to be $36 \mathrm{mEq}$. per 1. after glutamate. Urine collected during the last 14 hours of life contained 190 $\mathrm{mEq}$. of sodium and $77 \mathrm{mEq}$. of potassium.

At the start of glutamate therapy, the third patient (A. P.) had ascitic fluid drainage from an open abdominal wound created during an operation 9 days previously. This patient received hydrocortisone and antibiotic medication in addition to sodium glutamate; hydrocortisone was discontinued 3 days prior to death. A total of 355 grams of sodium glutamate were given over a 93hour period and the blood $\mathrm{NH}_{3}-\mathrm{N}$ concentration dropped from 2.6 gamma per $\mathrm{ml}$. and remained within normal limits, except for two slightly elevated levels both of 1.15 gamma per ml. obtained 22 and 19 hours prior to her death. The last determination was performed 15 hours before death. This patient exhibited improvement in mental state from third degree coma to first degree coma within 20 hours of starting glutamate, 
hydrocortisone, and antibiotics. Later the mental state fluctuated between third and fourth degree impending coma until 20 hours before death when hypotension, previously relieved by position, became pronounced. She then became oliguric and coma progressed to death. Terminally, guaiac positive material, some of which she aspirated, was obtained from the stomach. Tremor, absent in the initial comatose state, reappeared during improvement and finally disappeared during the last few hours of life. Again there was a drop in serum potassium (from 3.6 to $2.7 \mathrm{mEq}$. per L.) despite administration of $220 \mathrm{mEq}$. of potassium during her treatment. She lost $67 \mathrm{mEq}$. of potassium in the urine over two of the four days she was treated. Urine sodium loss was less than 2 $\mathrm{mEq}$. per day but a large amount was lost in the ascitic fluid (estimated loss 1 to 4 liters daily). Potassium loss in the ascitic fluid would have been comparatively slight.

\section{DISCUSSION}

Examination of mental state, the best method for describing degree or depth of coma, was used to evaluate the therapeutic efficacy of the sodium glutamate. The method is subjective, however, and daily or even hourly variations in the state of consciousness often occur. The prognosis of coma precipitated by known factors, such as ammoniumcontaining compounds, other drugs, high nitrogen intake, gastro-intestinal hemorrhage, infection, paracentesis, delirium tremens, and certain electrolyte disturbances, is almost certainly less severe than that of spontaneous hepatic coma (30). Also, when any of these precipitating factors is present, it is very difficult to evaluate a substance of unknown therapeutic value. Steps taken to insure an accurate evaluation of sodium glutamate's efficacy in hepatic coma included the following. $\mathrm{Pa}-$ tients were seen a minimum of two to three times daily by the same observer and were checked by others. Glutamate was administered (with two exceptions already mentioned) during a period when the depth of coma was increasing or when the state of consciousness appeared stabilized. If any factors known to precipitate hepatic coma were present, the patient was observed for at least one week until the mental state probably did not reflect the precipitating factors and only then was glutamate given (exception was patient A. P.). Patients were observed before the development of impending coma with three exceptions, and these were seen initially in impending coma. No other medications except supplementary potassium, cortisone, and antibiotics were given and these only to the patients mentioned. Therefore, with the exception of patient A. P., it seemed likely that any improvement resulted from sodium glutamate although the possibility of a spontaneous change cannot be eliminated entirely.

The presence of the tremor was useful in suggesting that confusion would soon appear. Fluctuations in confusion, when present, were not always paralleled by the severity of the tremor. The latter, often but not always absent in coma, may appear with improvement to impending coma (patient A. P.).

Our results indicate that 23 grams of sodium glutamate intravenously had little effect on the mental state, tremor, or plasma $\mathrm{NH}_{3}-\mathrm{N}$ concentrations of the first eight cirrhotic patients studied. Because, contrary to our findings in these eight patients, glutamate has been reported to lower venous blood "ammonia" levels and improve coma in some patients with chronic liver disease, larger quantities of this compound were tried in three patients with temporary improvement in mental state. No conclusions could be drawn in the third patient (A. P.), who also received adrenal steroids and antibiotics, except that glutamate did not prevent an eventual fatal outcome. A similar fate befell the other two patients; one expired while still receiving glutamate and the other five days after its discontinuance. The blood $\mathrm{NH}_{3}-\mathrm{N}$ concentrations were kept at or close to normal in all three patients during glutamate therapy, falling promptly from an initial elevation in two and rising $4 \frac{1}{2}$ hours after its discontinuation in one. This rise shortly after discontinuance of glutamate may explain the lack of significant change in plasma $\mathrm{NH}_{3}-\mathrm{N}$ concentrations in the first eight patients because determinations were done 14 to 18 hours after glutamate was discontinued.

Electrolyte disturbances might limit or otherwise effect the beneficial effect of a trial medication, although abnormalities were not stiking in the first eight patients who received only 23 grams of sodium glutamate daily. In the remaining three patients the main complication of administering large 
quantities of sodium glutamate was the development of hypokalemic alkalosis. Although the $\mathrm{pH}$ of the serum was not measured, there were elevations in serum carbon dioxide contents and sodium concentrations consistent with this abnormality in all three instances. The first patient experienced a marked drop in serum potassium, an increase in urinary potassium excretion, and did not receive potassium salts. Serum potassium concentrations also fell in the other two, despite terminal oliguria and administration of supplementary oral potassium in excess of their urinary potassium excretion. This latter finding seems not completely explained by the administration of large quantities of sodium although it has been shown in dogs that administration of sodium chloride may cause increased urinary potassium excretion (31). Administered glucose in large amounts with insulin present will often decrease serum potassium concentrations and might explain the low concentrations seen here. Despite the fact that these patients all received glucose this latter explanation alone seems doubtful because the severe hypokalemias did not respond to potassium administration, which is unusual in our experience. Although balance data are lacking, an additional possible explanation is that intracellular potassium may have increased during glutamate therapy accounting in part for the low serum potassium concentrations. We have not yet evaluated the effect of glutamic acid given as the potassium or magnesium salt.

The way in which large quantities of glutamate produced temporary improvement in hepatic coma remains obscure. Three possibilities exist as discussed by Weil-Malherbe (8). Because glutamate is necessary for maintenance of potassium gradients in guinea pig brain slices (32) one might wonder whether this action as well as the shown blood "ammonia" lowering effect produced mental improvement. A third effect of glutamic acid is to produce an adrenergic response (8). Whether this effect would account for improvement in hepatic coma is not known although some believe it is responsible for the favorable action of glutamate in insulin coma.

In summary it is realized that although results obtained with sodium glutamate were discouraging here and have been found so by others, the criteria set up for its evaluation were rigid. Its use may be more encouraging in other situations, i.e., hepatic coma precipitated by $\mathrm{NH}_{4}$ salts, a high protein intake, gastrointestinal hemorrhage, and possibly other factors. Good results have been observed in so-called "meat intoxication" of patients with portacaval shunts (33) and might also be found in patients with chronic liver disease and extensive collateral circulation in whom a somewhat similar situation exists.

\section{CONCLUSIONS}

1. Sodium glutamate, 23 grams intravenously daily, given to 8 of 11 patients with cirrhosis, failed either to affect favorably the course of spontaneous impending hepatic coma and coma or to prevent the onset or exacerbation of impending coma induced by ammonium salts. Plasma $\mathrm{NH}_{3}-\mathrm{N}$ concentrations showed no consistent change on the day following glutamate.

2. Much larger quantities of intravenous sodium glutamate had a temporary beneficial effect on the coma of two and possibly three other patients with cirrhosis. Peripheral venous blood $\mathrm{NH}_{3}-\mathrm{N}$ concentrations remained or became normal during the therapy.

3. A clinical method for evaluating the depth of hepatic coma or impending coma was found necessary and hence was developed and evaluated.

\section{REFERENCES}

1. Traeger, H. S., Gabuzda, G. J., Jr., Ballou, A. N., and Davidson, C. S., Blood "ammonia" concentration in liver disease, and liver coma. Metabolism, 1954, 3, 99.

2. Phillips, G. B., Schwartz, R., Gabuzda, G. J., Jr., and Davidson, C. S., The syndrome of impending hepatic coma in patients with cirrhosis of the liver given certain nitrogenous substances. New England J. Med., 1952, 247, 239.

3. Schwartz, R., Phillips, G. B., Seegmiller, J. E., Gabuzda, G. J., Jr., and Davidson, C. S., Dietary protein in the genesis of hepatic coma. New England J. Med., 1954, 251, 685.

4. Salaskin, S., Ueber das Ammoniak in physiologischer und pathologischer Hinsicht und die Rolle der Leber im Stoffwechsel stickstoffhaltiger Substanzen. Hoppe Seyler's Ztschr. f. physiol. Chem., 1898, 25, 449.

5. McDermott, W., and Adams, R. D., Eck-fistula: A cause of episodic stupor in humans. J. Clin. Invest., 1953, 32, 587.

6. McDermott, W. V., Jr., and Adams, R. D., Episodic stupor associated with an Eck fistula in the human 
with particular reference to the metabolism of ammonia. J. Clin. Invest., 1954, 33, 1.

7. Mayer-Gross, W., and Walker, J. W., The effect of L-glutamic acid and other amino-acids in hypoglycaemia. Biochem. J., 1949, 44, 92.

8. Weil-Malherbe, H., Significance of glutamic acid for the metabolism of nervous tissue. Physiol. Rev., 1950, 30, 549.

9. Walshe, J. M., The effect of glutamic acid on the coma of hepatic failure. Lancet, 1953, 1, 1075.

10. Schwartz, R., Unpublished data.

11. Woodrow, C. E., Froome, K., and Lawrence, I. H., Acute hepatic necrosis coma treated with sodium glutamate. Lancet, 1953, 2, 1290.

12. Singh, I. D., Barclay, J. A., and Cooke, W. T., Blood-ammonia levels in relation to hepatic coma and the administration of glutamic acid. Lancet, 1954, 1, 1004.

13. Webster, L. T., Jr., and Davidson, C. S., Hepatic coma: Effect of sodium glutamate. J. Clin. Invest., 1954, 33, 971.

14. Calvert, R. J., Smith, E., and Werren, J. P., The biochemistry and management of hepatic coma. A review and case report. Gastroenterology, 1954, 26, 650.

15. Riddell, A. G., and McDermott, W. V., Hepatic coma. Lancet, 1954, 1, 1263.

16. Alexander, J. W., and Porter, C. E., The treatment of a patient in hepatic coma with intravenous sodium glutamate and ACTH. Gastroenterology, 1954, 26, 926.

17. Westengaard, E., Iversen, H.-G.., and Larsen, V., Glutamic acid in hepatic coma. Danish Med. Bull., 1954, 1, 114.

18. Sherlock, S., Summerskill, W. H. J., White, L. P., and Phear, E. A., Portal-systemic encephalopathy. Neurological complications of liver disease. Lancet, 1954, 2, 453.

19. Cachin, M., Pergola, F., and Escaravage, M., Sur le traitement du coma hepatique par l'acide glutamique. Bull. et mém. Soc. méd. d. hôp. de Paris, 1954, 70, 910.

20. Decourt, J., Mornet, J., Ferandou, J., and Jerzaquet, R., Guérison d'un coma hepatique. Action décisive du glutamate de magnésium. Bull. et mém. Soc. méd. d. hôp. de Paris, 1954, 70, 850.

21. Van Slyke, D. D., and Neill, J. M., The determination of gases in blood and other solutions by vacuum extraction and manometric measurement. I. J. Biol. Chem., 1924, 61, 523.

22. Wallace, W. M., Holliday, M., Cushman, M., and E1kinton, J. R., The application of the internal standard flame photometer to the analysis of biologic material. J. Lab. \& Clin. Med., 1951, 37, 621.

23. Van Slyke, D. D., and Hiller, A., Application of Sendroy's iodometric chloride titration to proteincontaining fluids. J. Biol. Chem., 1947, 167, 107.

24. Owings, R. H., and Mandel, E. E., Studies in nonprotein nitrogen. I. A convenient method for measuring urea in blood. Proc. Soc. Exper. Biol. \& Med., 1951, 78, 363.

25. Seegmiller, J. E., Schwartz, R., and Davidson, C. S., The plasma "ammonia" and glutamine content in patients with hepatic coma. J. Clin. Invest., 1954, 33, 984.

26. Kirk, E., Amino acid and ammonia metabolism in liver diseases. Acta med. Scandinav., Suppl. 77, 1936.

27. Adams, R. D., and Foley, J. M., The neurological disorder associated with liver disease. A. Research Nerv. \& Ment. Dis., Proc., Vol. 32, Metabolic and Toxic Diseases of the Nervous System, Baltimore, Williams \& Wilkins Company, 1953, p. 198.

28. Phillips, G. B., Personal observations.

29. Adams, R. D., and Foley, J. M., The neurological changes in the more common types of severe liver disease. Tr. Am. Neurol. A., 1949, 74, 217.

30. Webster, L. T., Jr., Personal observations.

31. Baldwin, D., Kahana, E. M., and Clarke, R. W., Renal excretion of sodium and potassium in the dog. Am. J. Physiol., 1950, 162, 655.

32. Davies, R. E., and Krebs, H. A., Biochemical aspects of the transport of ions by nervous tissue. Biochem. Soc. Symposia No. 8, Metabolism and Function in Nervous Tissue, Cambridge, University Press, 1952, p. 77.

33. McDermott, W. B., Personal communication. 